International Journal of Linguistics, Literature and Translation (IJLLT)

ISSN: 2617-0299 (Online); ISSN: 2708-0099 (Print)

DOI: $10.32996 / \mathrm{jjllt}$

Journal Homepage: https://al-kindipublisher.com/index.php/ijllt

\title{
Attitude of Francophone Students towards Pidgin at the University of Buea (UB)
}

Blasius A. Chiatoh ${ }^{1}$ and Clovis N. Nkwain*2

${ }^{1}$ Associate Professor of Linguistics, Department of Linguistics, University of Buea, Cameroon

${ }^{2}$ Department of Linguistics, University of Buea, Cameroon

Corresponding Author: Clovis N. Nkwain, E-mail: clovis.ndichia@ubuea.c

\section{ARTICLE INFORMATION}

Received: October 12, 2020

Accepted: November 20, 2020

Volume: 3

Issue: 11

DOI: 10.32996/ijltt.2020.3.11.8

\section{KEYWORDS}

Attitude, unofficial language, LWC, competence

\section{ABSTRACT}

Although English is the official language of the University of Buea (UB), Cameroon Pidgin English (CPE) is quite commonly used on campus, particularly in extra curricula situations by Anglophones, who have it as their language of wider communication (LWC). However, Francophone students, some of whom meet CPE for their first time upon enrolment, tend to manifest much dislike for this language. Faced with the challenge of maximising the opportunities for learning and studying in English, a language in which they have limited spoken and written competence in, they view CPE as a sub-standard code, indeed, an impediment to the English language learning process. This paper surveys Francophone students' attitudes towards CPE at UB with focus on the underlying motivations for these attitudes. Data was elicited from a questionnaire administered to first-year Francophone students. The findings evince that Francophone students harbour unfriendly attitudes towards CPE.

\section{Introduction}

Cameroon Pidgin English (CPE) is the most widely spoken languages in Cameroon. According to Eberhard et al. (2019), the language has a total population of one million speakers with a majority of them in the Anglophone regions. Although generally considered as one of the outstanding and defining characteristics of Anglophone identity, the language is commonly spoken in some francophone regions, particularly in the western region (Mba, 2013, p. 14). In the Anglophone regions, it is the language of everyday interaction for both the literate and non-literate populations. It is very prominent in religious and commercial circles; it is even a native tongue to a non-negligible number of the plantation workers in the Southwest region. Despite the crucial functions that the language plays in the society, it enjoys an extremely low prestige within educational circles where it is widely regarded as one of the key causes of the stead fall in the standards of English.

Of all the towns where CPE is spoken, Buea is the town that has attracted a majority of Francophone students in search of English-oriented education. Yet, UB is one of the educational institutions where CPE is expressly prohibited. However, the reality within the student community is quite different. Out of the classroom, students discuss academic and other topics in their language of social interaction - CPE. The use of CPE has proliferated on the UB campus to the extent that English seems to occupy a secondary position. In fact, even lecturers and general staff appear to be more comfortable discussing business in CPE. This, added to the anxiety to learn English, has led Francophone students, especially freshmen and women to look down on the language.

The apparent difference between UB institutional norms on the one hand and students' language choice on the other seem to explain why Francophone students find the language as a threat to their proper acquisition and mastery of English. In addition, given that they come with prejudices against the language, one can hardly lay the blame for their dislike for CPE entirely on institutional norms. In this study, we investigate the motivations for these attitudes in a bid to explicate the

AL-KINDI CENTER

FOR RESEARCH AND

$\mathbf{R}$ D FOR RESEARCH

Your gateway to world-class research
Published by Al-KindiCenter for Research and Development. Copyright (c) the author(s). This is an open access article under CC BY license (https://creativecommons.org/licenses/by/4.0/) 
instrumental motivation for learning English given that sentimental motivation customarily demands respect for, and acknowledgement of CPE as the core defining variables of Anglophone identity.

\section{Cameroon Pidgin English in a multilingual Cameroon}

English is an official language (by implication Francophones' second official language), indeed, the standard variety for Francophone students as per the Cameroon Constitution. CPE on its part exists as a common code or means of interaction between speakers of different indigenous languages across the national territory and has an everyday increase in the number of users (see Simo Bobda, 2004, p. 9). It is also a marker of Anglophone identity in the sense that it is the language an average Anglophone uses most. This is particularly noticeable when conversations between Anglophones in English quite often naturally switch to CPE. It is almost just certain that some conversations among Anglophones are better discussed only in $\mathrm{CPE}$, especially among those individuals for whom CPE is a first language (L1). This phenomenon, however, causes francophone students to distinguish themselves from those who are bona fide speakers of CPE. In a study on language attitude, Finch (n.d.) depicts this when he explains that mind-set in every sense represents the reality for the group that possesses it. This assertion validates the view that behaviour is linked to personal motivation as the attitude put forward by Francophones is driven by their motivation to learn English (p. 15). Still borrowing from Finch (n.d.), the reality with his contention is that any variety of English that is not pidginised, is looked upon as Standard English by Francophone students: the variety they want to identify with. The reality with this, however, is that sometimes the constructions they mistake for appropriate usage (British Standard English) actually constitute Cameroon indigenised English; a variety of Cameroon English that is close to a Pidgin. This situation can be likened to Korean students in the USA, who perceive all varieties of English as standard American English (Chang, 2005 as cited in Kim, 2007, p. 1).

In Cameroon, CPE is generally considered as a poor variety of English and so despised by many including some educated Anglophones. As a trade language, CPE is spoken largely as a second language by a wide majority of the Anglophone population and as a mother tongue by a small, yet not insignificant minority particularly in plantation areas. It is also common in some communities, to hear families that speak an indigenous mother tongue using CPE as a means of daily communication. Despite the wide scope of its usage, it is associated with almost everything backward and primitive. From a status planning perspective, the language does not enjoy government recognition and, as a result, has been referred to by some as Bush English.

One interesting characteristic of CPE in Cameroon is its association with Anglophone identity. In their quest for identification and assertion in a multilingual country that enjoys de facto French domination, Anglophones have come to recognise CPE as one of the fundamental markers of their identity. This has come with its own array of problems. What this has meant to the majority francophone population is that Anglophones are referred to derogatorily as 'pidginophones' on grounds that a vast majority of them speaks CPE as a second language as compared with francophones who speak mostly French and their indigenous mother tongues. While French is regarded as a standard (civilised) language, CPE is viewed as a sub-standard (primitive) language with the implication being that francophone students do not want to be associated with the language for fear of being considered social misfits. Yet CPE is a language in its own right although its vocabulary borrows extensively from English language and to an extent from indigenous languages. As indicated earlier, its territorial space is not limited to Anglophone regions; it is also spoken in Francophone regions (Eberhard et al., 2019). Given the richness of its vocabulary and the wide scope of its use, it seems unacceptable that identifying with this language becomes the basis for negative social labelling. In fact, the choice for a particular language cannot be a criterion to judge or measure some group of people or to label or classify them as social misfits except from the stance of resentment for and negative connotations towards a people. As Baker (1992) asserts, attitude involves feelings and beliefs as social indicators that cause people to behave in a particular way. This is because attitudes develop from beliefs that influence behaviour. This mind-set reflected in these students are ill conceived because CPE is not only the most spoken language in this region, but also a marker of identity for Anglophones. As such, deliberately avoiding a language that has native speakers only suggests that negative connotations are tagged to their decision (p. 9). Edwards (1982) also presents three enabling possibilities of the essential patterns of speech-style judgments that bring about language attitude. These patterns either reflect (1) intrinsic linguistic superiorities/inferiorities; (2) intrinsic aesthetic differences; or (3) social convention and preference. However, even though this is ostensibly the case with CPE, Edwards (1982) also notes that it is sociolinguistically unpleasant for languages and language varieties to be reasonably described, as (1) above- "better/worse".

\section{State of the Art}

Research on language attitude over the years has hardly investigated or presented causal factors attributed to attitude. Rather, it focuses on interaction and the findings vary across variables such as culture, dialect, accent, and context (see Giles \& Billings, 2004). Nonetheless, in the Cameroonian context, attitude is more narrowed to linguistic superiority/minority 
dimension, and most educationists and linguists tend to blame poor acquisition of the grammar of Standard English, the language most people want to identify with on campus; a variety very close to the English spoken in Cameroon (see Ayafor, 1996 as cited in Fontem, 2004; Ndongmanji, 2005, p. 217) instead of focusing on the learners' attitudes towards these languages. However, even though no research presents Cameroonians' choices of language(s), especially in education, the tendency is to opt for foreign languages as the best languages to express patriotism, to get a job or a chance to improve the future of the youths' (Mckenzie, 2010, p. 36). As a result, these neutral (foreign) languages are imposed on the citizens without prior considerations of the attending consequences.

Therefore, from the stance of educationists and linguists, CPE is a language that stands to deter the proper acquisition or mastery of English. It is no wonder that Francophone students on arriving UB have already developed prejudices towards and its users; they seem to think that they cannot learn anything valuable from speaking such a language. A lot has been done on $\mathrm{CPE}$, but research on it has in the past, focused more or less on its spread and number of speakers in Cameroon (see Koenig et al., 1983; Todd, 1995; Schroeder, 2003).

\section{Theoretical Framework}

We employed the mentalist approach as used within social psychology to explain the findings in this study. This approach considers attitude as an "internal state of readiness" which can affect the responses of individuals if stirred to a certain point. By implication, we cannot directly discern attitudes. According to Eagly and Chaiken (1998), attitudes can only be inferred from the respondents themselves. That is, attitudes are not observed directly but are rather portrayed through behaviour (for the most part), how other people refer to speakers of other languages or the desire whether to learn another language or not (as cited in Mckenzie, 2010). Attitude is mostly seen to comprise cognitive, affective (emotional) and conative (individual predisposition to behave in a certain way) reinforcements. However, studies have also shown that not all of these must be depicted in a particular situation or made distinct from one another (Appel \& Muysken, 1987, p. 16; Bohner \& Wanke, 2002, p. 5). For this reason, we have also categorised them as positive or negative based on Bohner and Wanke (2002) who further note that attitude is the main determining factor of behaviour if accurately measured (pp. 219-244).

\section{Methodology}

This study sampled first-year Francophone students of the Departments of English and Linguistics at the University of Buea. These departments had 100 first-year francophone students among whom 75 were females. First-year students were chosen because they had not become too used to Anglophones and CPE their LWC. Out of this number, fifty (50) students were sampled among whom, 35 students (75\%) were females and $15(25 \%)$ to ensure that the sample was representative enough.

We employed the direct method and questionnaires were structured and administered to the students to get an account of their attitudes towards CPE with a variety of questions (that incorporated elements of Mentalism to determine respondents' attitude). Each question was formulated to measure a distinct concern and to yield a score that was specific to that concern. The first part of the questionnaire addressed the intent of the study and equally assured the respondents of the confidentiality of the data to be got. The second part contained close ended questions, inviting the respondents to give appropriate responses which took the shape of 'yes/no', self-scale and a question of gender. The target population was numbered on different pieces of paper and put into trays representing females on the one hand and males on the other and a neutral person was asked to pick the required number of pieces from the different trays in a bid to ensure that all the francophone students were given a fair chance of being selected. The questionnaires were piloted to second-year francophone students of these departments. This was intended to ensure that the items and structure of the questions reflected what we had intended to elicit so that indispensable corrections could still be made before administering to the final sample to ensure the appropriateness, meaningfulness and usefulness of inferences made from the data were. After administration, we screened and cleaned the data by checking for contradictory responses on the questionnaire (answering a follow up question, when the main question had not been answered). We used simple percentages to present and discuss the data.

\section{Presentation of Findings and Analysis}

Here, we sought to identify the languages francophone students use at UB. The findings indicated that most of the respondents did not speak CPE. 31 (62\%) respondents said that they did not speak CPE, while 19 (38\%) spoke CPE. The 62\% who did not speak CPE, shows that the motivation to learn English among francophone students is high. This is confirmed by the fact that they came to UB to learn English and specifically by studying in English; a goal they did not want to compromise by using CPE. 
Figure 1. Background information on languages used among them at UB

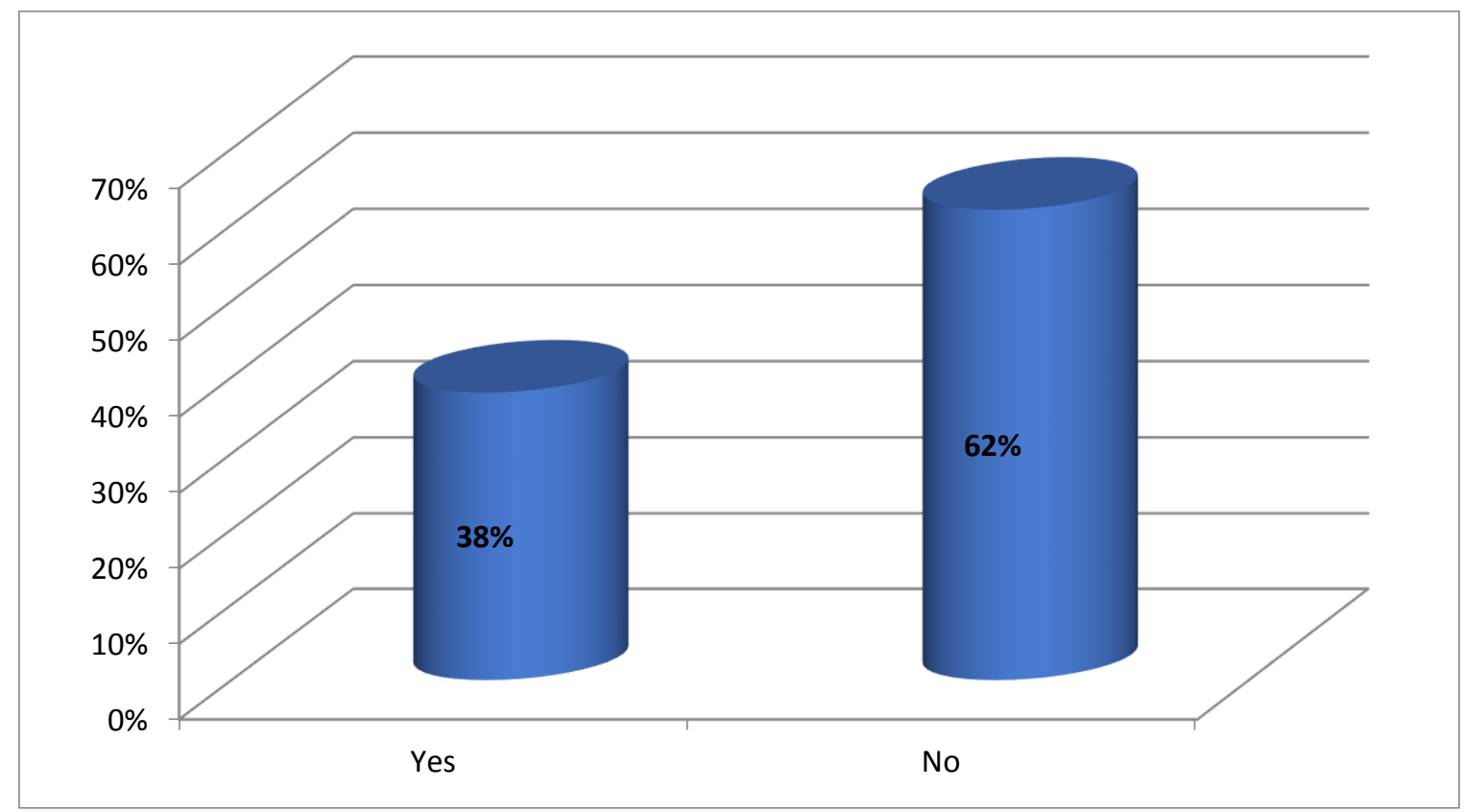

With regard to how long they had been speaking CPE, 16 of them said that they had been using CPE before 2016 when they first got to UB; apart from $3(16 \%)$ that said they started speaking CPE only when they came to UB. Out of the 16 who had been using CPE before they came to UB, 8 (42\%) had been using CPE since 2012, $4(21 \%)$ since 2010, and another $4(21 \%)$ since childhood as presented in Figure 2 below.

Here, we noticed that out of the 19 respondents who confirmed that they spoke CPE (as mentioned in Fig. 1), 16 of them used to speak CPE before they came to UB and only 3 started speaking CPE upon admission. This, perhaps, explains the fact that CPE is common in the both the Anglophone and francophone regions. This finding is similar to that of Mba (2013) who points out that in addition to the Anglophone zone, CPE is equally used in the Littoral and the West regions of Cameroon ( $p$. 14). Therefore, it is interesting to understand that their reluctance to use this language is strictly premised on prejudices that they have developed prior to their arrival at the UB.

Figure 2. How long the respondents had been using CPE

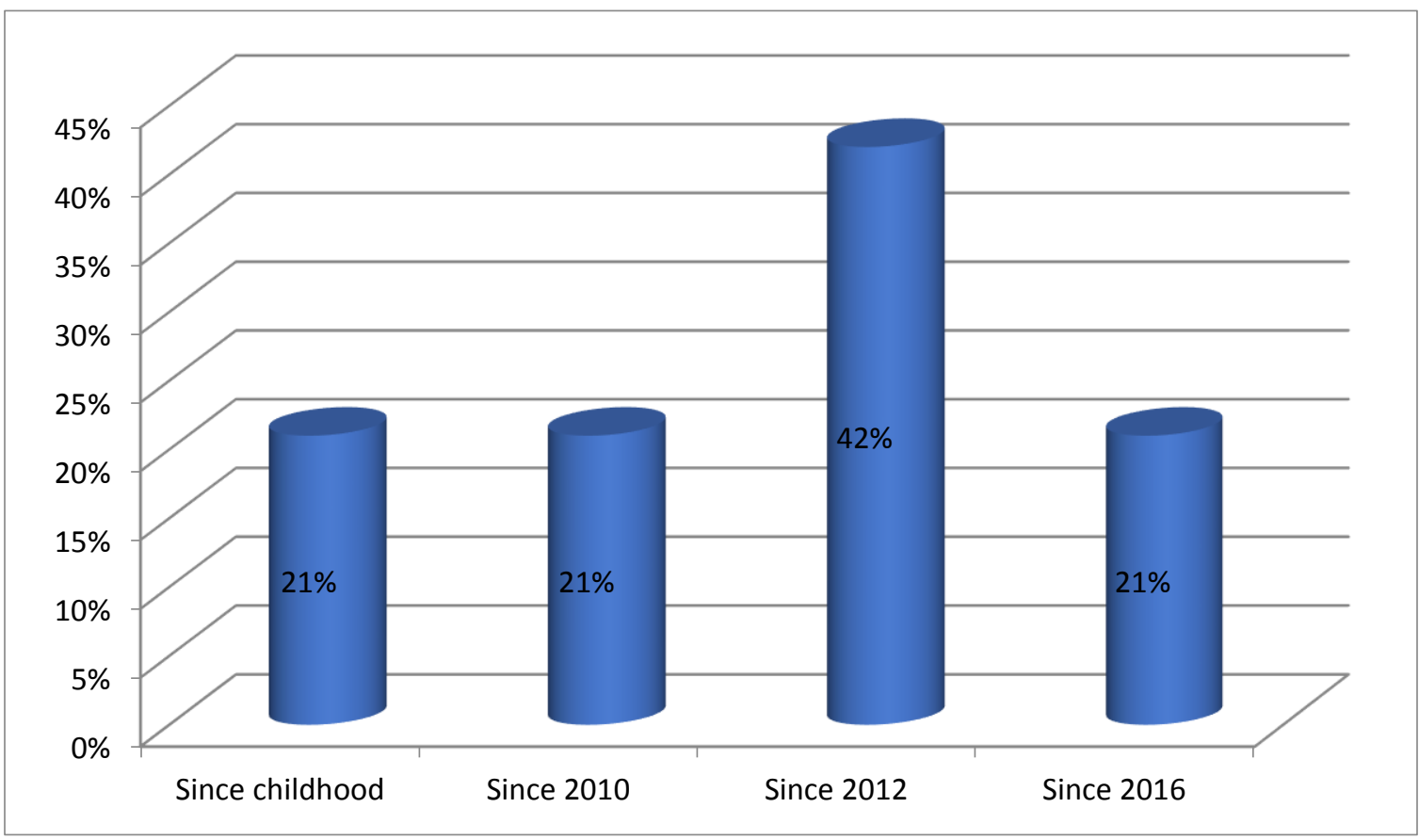


Concerning their proficiency in CPE and their frequency of use of the language, we observed that out of these 19 respondents who spoke CPE, 7 could speak CPE very well and another 7 fairly and only 4 equally used CPE always and 8 used it sometimes. We equally noted that no matter their proficiency in CPE as represented by 7 (14\%) for very good, another $7(14 \%)$ for average, $8(16 \%)$ spoke CPE sometimes and only $4(8 \%)$ spoke CPE always. $8(16 \%)$ and $28(56 \%)$ for poor and very poor respectively, explains why $13(26 \%)$ rarely used CPE and $15(30 \%)$ never used CPE. CPE and English constitute the linguistic scenery of the UB campus and it is only obvious that the vocabulary of CPE should greatly enrich their vocabulary of English. The complete refusal to speak CPE with Anglophones, when in fact francophone students can produce meaningful utterances in it indicates that they want to avoid this language at all costs

Figure 3. Proficiency and frequency of use of CPE

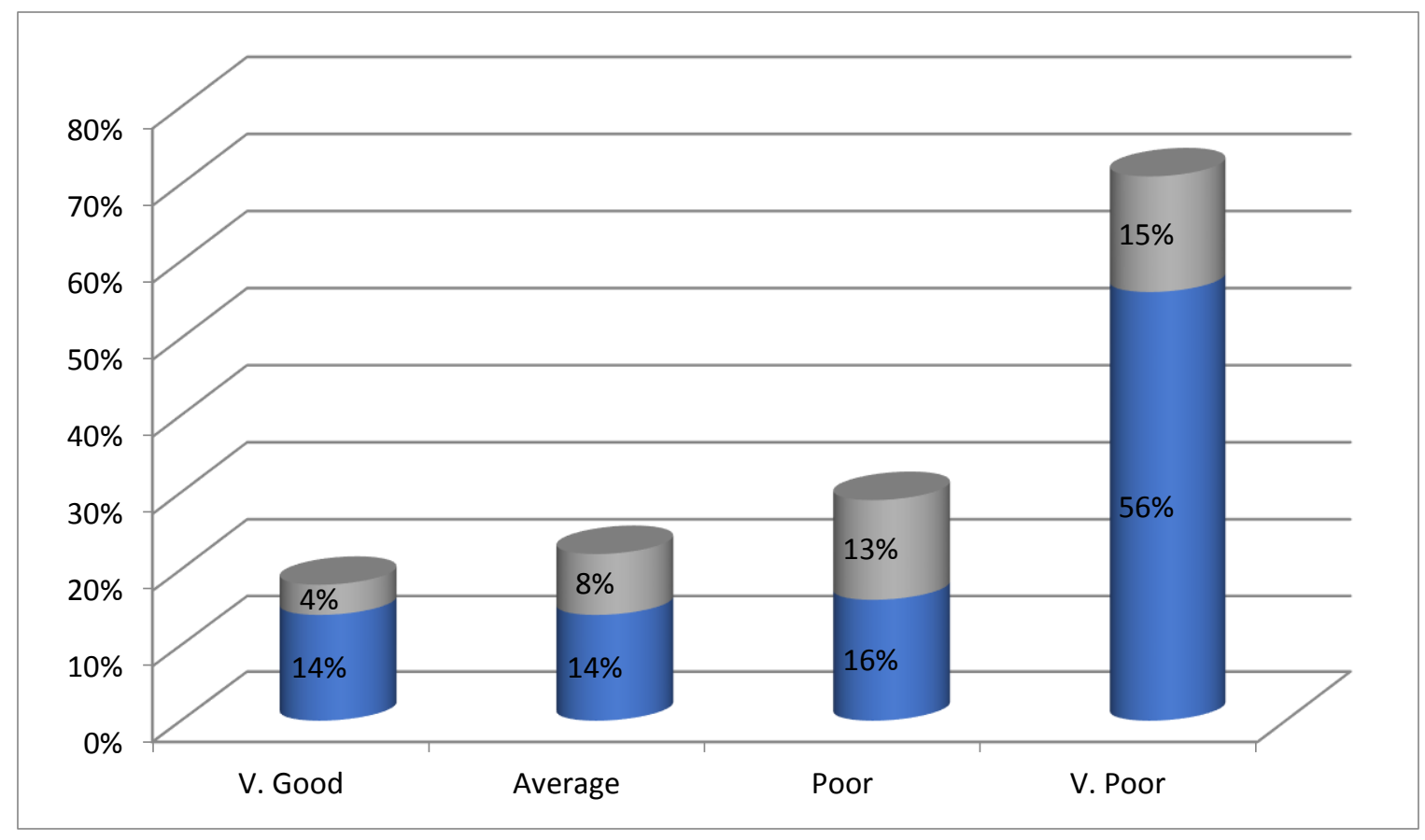

Pertaining to how many of them had Anglophone friends, and for how long they could sustain a conversation with them in CPE, 49 (98\%) said they had Anglophone friends, while 1(2\%) did not have (an Anglophone) friend(s). As shown in Figure 3, some of the respondents who spoke CPE sometime and those who spoke CPE always, representing 7 (14\%) in Table 1 said that they could sustain a conversation for more than 21 minutes in CPE. This explains the fact that human actions can be influenced by perceived social pressure to perform the behaviour (Siragusa \& Dixon, 2009, p. 971).

Table 1. Number of respondents who had Anglophone friends and the duration they could sustain a conversation in CPE

\begin{tabular}{lllll}
\hline Responses & $\mathbf{N}^{\circ}$ who had & $\mathbf{N}^{\circ}$ who did not & Total \\
\hline Respondents & 49 & 1 & & 50 \\
Percentage & 98 & 2 & 21 and above & 100 \\
$N^{\circ}$ of minutes & $0-10$ & $11-20$ & 7 & 50 \\
Respondents & 35 & 8 & 14 & 100 \\
Percentage & 70 & 16 & 100 \\
\hline
\end{tabular}

As concerns which language they would prefer to use, 27 (54\%) said that they would prefer English and 10 (20\%) said that they would prefer an indigenous language. However, $8(16 \%)$ and $5(10 \%)$ would prefer Camfranglais and French respectively.

A majority of the respondents representing 27 (54\%) chose English as their most preferred language in the place of CPE. This is followed by indigenous languages with $20 \%$. However, Camfranglais, which is a kind of pidginised tongue that combines 
elements of French and English, followed with 8 (16\%). French, the language in which they already have written and spoken competence in was the last option.

Figure 5. Choice of language the respondents preferred over CPE

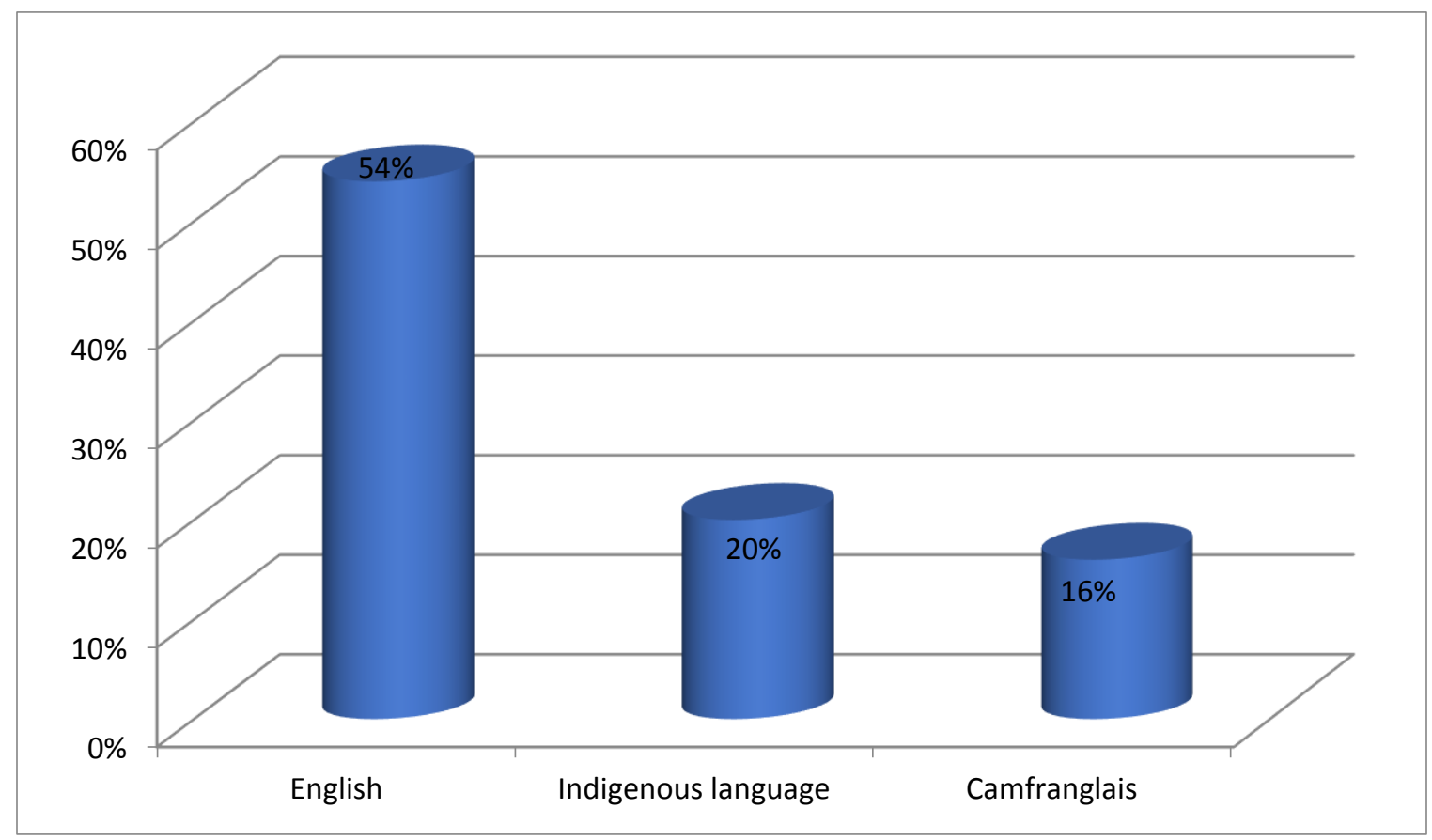

Cognitive, affective and conative components of attitudes as elicited from responses based on the reason why CPE is their last choice of preferred language(s)

From the responses elicited, there is really no clear distinction between affective, cognitive, and conative components of attitude. This view is already mentioned in Eagly and Chaiken (1998) as cited in Papapavlou and Mavromati (2017, p. 2). Based on the aim of this study, which investigates the underlying motivations for this attitude towards CPE in order to explicate their instrumental motivation for learning English given that sentimental motivation invariably demands respect for, and acknowledgement of CPE as the core defining variables of Anglophone identity, we emphasise on the positive and negative aspects of attitude. This is because we might choose to say ii, vii, ix and $x$ as presented below are affective components because they are emotional responses that show the respondents appreciation or disgust. However, these same responses can be considered as a cognitive element because they are just individual beliefs. In addition, these (affective and cognitive) bring about the respondent bias in mingling with Anglophones thereby revealing another component of attitude (conative).

i. CPE is used to debunk fun/jokes. (Positive conative)

ii. It is difficult to learn and should be used only for business. (Positive cognitive)

iii. It is bizarre because people no longer speak Standard English because of it. (Negative cognitive)

iv. It destroys the English we already know. (Negative cognitive)

v. It reduces proficiency of English. (Negative cognitive)

vi. It kills English language. (Negative conative)

vii. It is a rude and rough language. (Negative affective)

viii. It is local and not international. (Negative cognitive)

ix. It damages one's First Languages. (Negative affective)

$x$. It is not a good language. (Negative affective) 


\section{Conclusion}

In this paper, we have attempted an analysis of francophone students' attitude towards CPE at UB, an institution whose language of instruction is the English language. Our findings point to the fact that a majority of Francophone students consider CPE as a substandard code perhaps and so have negative attitudes towards it. Upon enrolment, they have already developed prejudices against CPE and its use as evidenced in the fact that some of them actually communicate with Anglophone students in this language. To demonstrate their dislike for the language, they become very selective in their choices of social relationships; they only choose as friends Anglophone students who use CPE less often. The findings of this study reinforce our understanding of the challenge that CPE faces as a language in Cameroon in general and at the University of Buea in particular. The findings suggest that without the assignment of official status to CPE, it is most likely to continue to be considered as the language of the backyard by a majority of the national population.

\section{References}

[1] Appel, R., \& Muysken, P. (1987). Language contact and bilingualism. Edward Arnold.

[2] Baker, C. (1992). Attitudes and language. Multilingual Matters.

[3] Fontem, N. (2004). Investigating modes of language acquisition and proficiency. Miraclaire Publishing.

[4] Bohner, G., \& Wanke, M. (2002). Attitudes and attitude change. Psychology Press.

[5] Eberhard, D. M., Simons, G. F., \& Fennig, C. D. (Eds.). (2019). Ethnologue: Languages of the world (22nd ed.). SIL International. http://www.ethnologue.com

[6] Edwards, J. R. (1982) Language attitudes and their implications among English speakers. In E. B. Ryan, \& H. Giles (Eds.), Attitudes towards language variation (pp. 20-33). Edward Arnold.

[7] Finch, A. E. (n.d.). Promoting positive attitude change: Interactive learner journals. Kyungpook: KyungookNational University Press. www.finchpark.com/arts/LJ_Agent_Attitude_Change

[8] Giles, H., \&Billings, A. C. (2004). Assessing language attitudes: Speaker evaluation studies. In A. Davies, \& C. Elder (Eds.), The Handbook of Applied Linguistics (pp. 187-210). Blackwell.

[9] Kim, Y. S. (2007). Korean adults' attitudes towards varieties of English (MSc thesis). University of Edinburgh. http://www.era.lib.ed.ac.uk/bitstream/1842/1903/1/Korean

[10] Koenig, E. L., Chia, E., \& Povey, J. (Eds.). (1983). A sociolinguistic profile of urban centres in Cameroon. Crossroads Press.

[11] Mba, G. (2013). An overview of language policy and planning in Cameroon. In P. W. Akumbu, \& B. A. Chiatoh (Eds.), Language Policy in Africa: Perspectives for Cameroon (pp. 12-31). Miraclaire Academic Publications.

[12] McKenzie, R. M. (2010). The social psychology of English as a global language: Attitudes, awareness and identity in the Japanese context. Springer.

[13] Ndongmanji, J. (2005). Effective communication in English: A review of traditional grammar and the problem areas of non-native speakers. Willy Printers.

[14] Papapavlou, A., \& Mavromati, A. (2017). Bridging language attitudes with perceived language notions. Open Journal of Modern Linguistics, 7(2), 167-183. doi: 10.4236/ojml.2017.72013

[15] Schroeder, J. (2003). Status, functions and prospects of Pidgin English: An empirical approach to language dynamics. Gunter Narr Verlag Tubingen.

[16] Simo Bobda, A. (2004). Life in the tower of Babel without a language policy. General and Theoretical Papers. http://www.linse.unidue.de/linse/laud/index.html

[17] Siragusa, L., \& Dixon, K. C. (2009) Theory of planned behaviour: Higher education students' attitudes towards ICT-based learning interactions in Same places, different spaces. Proceedings ascilite Auckland 2009 (pp. 969980).http://www.ascilite.org.au/conferences/auckland09/procs/siragusa.pdf

[18] Todd, L. (1995). Tracking the homing Pidgin: A millennium report. English Today, 11, 33-41. 